\title{
The haemocytic origin of lymphoid organ spheroid cells in the penaeid prawn Penaeus monodon
}

\author{
Margaretha S. Anggraeni, Leigh Owens* \\ Department of Microbiology and Immunology, James Cook University 4811, Australia
}

\begin{abstract}
Studies on lymphoid organ spheroid (LOS) cells of Penaeus monodon were undertaken. Phenoloxidase and peroxidase assays showed that LOS cells have characteristics similar to semi-granular and, in particular, large granular haemocytes. The mean percentage of LOS cells positive for phenoloxidase and peroxidase was $85 \pm 23$ and $82 \pm 23 \%$, respectively. There was no significant difference between the sites of phenoloxidase and peroxidase activity in LOS cells $(t=1.617, \mathrm{df}=29, \mathrm{p}>0.05)$. The relative sectional area occupied by LOS cells relative to that of the stromal matrix cells from both laboratory-held and farmed prawns was not correlated to increasing weight or total length of the prawns $(p>0.05)$. An apoptosis detection assay showed that LOS cells were often apoptotic whilst stromal matrix cells were not. There was a significant difference $(t=-5.533, \mathrm{df}=58, \mathrm{p}<0.05)$ in the mean percentage of apoptotic spheroid cells between laboratory-held prawns (52 $\pm 24 \%$ ) and farmed prawns with midcrop mortality syndrome (MCMS) $(80 \pm 12 \%)$. In conclusion, LOS cells have the characteristics of exocytosed, granular haemocytes that have phagocytosed foreign material, particularly viruses, and probably constitute a major mechanism for penaeid antiviral defense.
\end{abstract}

KEY WORDS: Penaeus monodon - Haemocyte - Lymphoid organ - Spheroid cells · Prophenoloxidase Peroxidase A Apoptosis - Midcrop mortality syndrome

\section{INTRODUCTION}

Oka (1969) first described the lymphoid organ (LO) in the penaeid prawn Penaeus orientalis, and later Martin et al. (1987) incorrectly described the LO structure as haematopoietic nodules in the ridgeback prawn Sicyonia ingentis. Bell \& Lightner (1988) described the normal structure of LO of penaeid shrimp. It was generally believed that the LO in penaeids played an important role in the immune response (Kondo et al. 1994, Martin et al. 1996). Studies by Martin et al. (1996) on the role of lymphoid tissue (incorrectly termed haematopoietic tissue) of ridgeback prawn $S$. ingentis revealed that lymphoid nodules were the most specific and effective organ for bacterial clearing. Special tissue changes in penaeid LO called spheroids have been associated with viral infection, i.e. 'Nakamura organ' hypertrophy and metastasis (Lightner et al. 1987), lymphoidal parvo-like virus (Owens et al.

•Corresponding author. E-mail: leigh.owens@jcu.edu.au
1991, 1992), LO vacuolization virus (Bonami et al 1992), rhabdovirus of penaeid shrimp (Nadala et al 1992), yellow head virus (Boonyaratpalin et al. 1993) LO virus (Spann et al. 1995), spawner-isolated mortality virus (Fraser \& Owens 1996) and Taura virus (Has son et al. 1995). Besides normal LO matrix cells, Lightner et al. (1987) found in the 'Nakamura (lymphoid) organ' of Penaeus monodon and Penaeus penicillatus that there were extremely active spheroid clumps of what were described as hyperplastic tubules that lacked a central vessel. Lightner (1996) also proposed that Penaeus vannamei infected with LO vacuolization virus showed LO spheroids comprising disorganised LO tubules that lacked a central vessel and consisted of cells that showed karyomegaly, large prominent cytoplasmic vacuoles and other cytoplasmic inclusions Moreover, Owens (unpubl. data) has classified changes in lymphoid organ spheroid (LOS) cells into 3 phases. First is a tumorous-like phase that does not have any encapsulating fibrocytes around the spheroids (as described in spawner-isolated mortality virus infection by Fraser \& Owens (1996). Second is a fully 
encapsulated spheroid phase as described in lymphoidal parvo-like virus infection (Owens et al. 1991) and LO virus infection (Spann et al. 1995). Third is vacuolative degeneration of spheroids which was reported first by Owens \& Hall-Mendelin in 1989 (Owens \& Hall-Mendelin 1990) but was also described in LO vacuolization virus infections (Bonami et al. 1992). Lightner et al. (1987) also described ectopic metastatic spheroids in the cuticular hypodermis of $P$. vannamei. Despite the detection of several disease agents in the LO of prawns, its role, particularly with respect to spheroid cells, still remains unclear.

Haemocytes are considered the primary line of internal defence against infection in Crustacea, and they have therefore been studied in some detail. The crustacean cellular defence system consists of sequential coagulation, phagocytosis, encapsulation, and nodule formation (Fontaine \& Lightner 1974, Bauchau 1981, Suderhall \& Cerenius 1992). Once stimulated by foreign particles (Song \& Hsieh 1994), haemocytes can produce highly reactive oxygen radicals such as superoxide anion $\left(\mathrm{O}_{2}^{-}\right)$, hydrogen peroxide $\left(\mathrm{H}_{2} \mathrm{O}_{2}\right)$ and hydroxide ions $\left(\mathrm{OH}^{-}\right)$. According to Deimann (1984), endogenous peroxidase can be visually located in tissues by its catalytic $\mathrm{H}_{2} \mathrm{O}_{2}$ oxidation of DAB (3,3-diaminobenzidine tetrahydrochloride). The prophenoloxidase system, besides producing highly reactive oxygen radicals, also activates certain types of haemocytes. Through an enzyme cascade, prophenoloxidase is converted into phenoloxidase (PO) in the terminal phase. The latter participates in cellular defence by opsonising cells for encapsulation (Johansson \& Soderhall 1985, 1989, Aspan \& Soderhall 1991, Kondo et al. 1992), and by participating in melanization reactions (Soderhall \& Cerenius 1992, Adams 1994), nodule formation (Smith et al. 1984, Adams 1994), and phagocytosis (Smith \& Soderhall 1983, Soderhall et al. 1986, Kondo et al. 1992, Adams 1994). PO activity can be detected by observing the formation of dopachrome from L-DOPA (dihydroxyphenylalanine).

This paper describes the role of haemocytes in the production of LOS cells in penaeid prawns (the term 'spheroid cells' will be used throughout the rest of the paper).

\section{MATERIAL AND METHODS}

Preliminary studies. Preliminary studies were conducted to evaluate and modify techniques that could be applied easily to the LOs of prawns. Included were the preparations of smears and sections, such as impression smears (Vickers et al. 1993), frozen sections (Lillie \& Fulmer 1976), paraffin-embedded tissue sections (Bell \& Lightner 1988) and different staining pro- cedures for detecting oxygen free radicals using nitroblue tetrazolium (Song \& Hsieh 1994), and 3,3diaminobenzidine tetrahydrochloride (Fahimi 1979, Sequeira et al. 1995). The following procedures describe the methods which gave the best results.

Prawns. The prawns used in all trials were Penaeus monodon from commercial farms in northern Queensland, Australia. For the 'area analysis' study, 20 prawns which had been kept for over 1 mo in the laboratory at James Cook University and had a final weight of $8.1 \pm$ $3.3 \mathrm{~g}$ and a total length of $10.9 \pm 1.3 \mathrm{~cm}$ were compared to 20 prawns from a different commercial farm with a final weight of $8.3 \pm 5.0 \mathrm{~g}$ and a total length of $10.0 \pm$ $1.8 \mathrm{~cm}$.

Thirty prawns which had been kept for over 1 mo in the laboratory and had a final weight of $7.5 \pm 3.1 \mathrm{~g}$ and a total length of $10.3 \pm 1.1 \mathrm{~cm}$ were used for assessment of $\mathrm{PO}$ activity, peroxidase activity, in situ hybridization assay and apoptosis detection assay. From a commercial farm, another 30 prawns which had been diagnosed by the Oonoonba Veterinary Laboratory as suffering from midcrop mortality syndrome (MCMS) and had a final weight of $7.9 \pm 4.7 \mathrm{~g}$ and a total length of $8.5 \pm 2.1 \mathrm{~cm}$ were also tested for apoptotic cells. These prawns were gene-probed by in situ hybridisation to Spawner-isolated Mortality Virus (SMV) (Owens et al. 1998) and found to be positive to this virus. SMV is one of a suite of viruses found in prawns affected by MCMS

Paraffin-embedded tissues. The prawns were preserved in Davidson's fixative (Bell \& Lightner 1988) by injecting $0.5 \mathrm{ml}$ of the fixative directly into the hepatopancreas and adjacent areas of the cephalothorax of each prawn. After $24 \mathrm{~h}$ in Davidson's fixative, the cephalothorax was cut in half longitudinally, placed in a histocassette, transfered to $70 \%$ ethanol, and then processed for routine histological examination using standard paraffin-embedded procedures as described by Bell \& Lightner (1988).

Peroxidase activity assay. The peroxidase assay was adapted from Sequeira et al. (1995), who observed the peroxidase activity in haemocytes of Penaeus japonicus. Five $\mu \mathrm{m}$ tissue sections were placed on a glass slide, incubated at $60^{\circ} \mathrm{C}$ for $1 \mathrm{~h}$, dewaxed in xylene and absolute ethanol, washed by immersion in $0.1 \mathrm{M}$ Tris$\mathrm{HCl}$ buffer (pH 7.4), and then incubated in the dark in $0.1 \mathrm{M}$ Tris $-\mathrm{HCl}$ buffer containing $2 \mathrm{mg} \mathrm{ml}^{-1} \mathrm{DAB}$ and $0.003 \% \mathrm{H}_{2} \mathrm{O}_{2}$ for $3 \mathrm{~h}$ at $30^{\circ} \mathrm{C}$. The sections were examined under a light microscope, and dark brown to black staining of granules was interpreted as presence of peroxidase activity.

Prophenoloxidase activating system assay. Prawn tissues were cut at $5 \mu \mathrm{m}$, placed on a silanized glass slide, incubated at $60^{\circ} \mathrm{C}$ for $1 \mathrm{~h}$, dewaxed in xylene and absolute ethanol, and then tested for PO activity using 
the method of Hose et al. (1987), who observed what he called the pro-PO system in haemocytes of the ridgeback prawn Sicyonia ingentis. Tissues were washed by immersion in $0.1 \mathrm{M}$ phosphate buffered saline (PBS) (pH 7.4) for 1 min, post-fixed in $2.5 \%$ glutaraldehyde in $0.1 \mathrm{MPBS}$ for $1 \mathrm{~h}$ at $4^{\circ} \mathrm{C}$, rinsed 3 times for $5 \mathrm{~min}$ each in $0.1 \mathrm{M}$ PBS, incubated in $0.1 \%$ $\mathrm{L}$-DOPA in $0.1 \mathrm{M}$ PBS for $16 \mathrm{~h}$ in the dark at room temperature, and then examined by light microscopy for dark brown staining of the granules interpreted as PO activity.

Area analysis. After embedding in paraffin, tissues were cut at $5 \mu \mathrm{m}$ and stained with H\&E. The area of spheroid cells and stromal matrix cells was observed by light microscopy and analyzed using Jandel Scientific Software: Sigma Scan and Sigma Scan Pro (image measurement software and automated image analysis software).

In situ hybridization. The in situ hybridization probe used for this assay was derived from the prawn $18 \mathrm{~S}$ rRNA gene and prepared by Dr Catriona McElnea (Department of Microbiology and Immunology, James Cook University) based on published sequences by Kim \& Abele (1990). The protocol was adapted from HPV-IS kit for hepatopancreatic parvovirus from DiagXatics, Inc., Wilton, CT, USA, with the following modifications. Tissue sections were permeabilised with $100 \mu \mathrm{g} \mathrm{ml} \mathrm{m}^{-1}$ Proteinase $\mathrm{K}$ for $10 \mathrm{~min}$ at $56^{\circ} \mathrm{C}$ and then slides were washed with sterile water following stabilisation with cold $0.4 \%$ paraformaldehyde and allowed to air dry. The 18sRNA probe was then applied to the slide at $1 \mathrm{ng} \mathrm{ul}^{-1}$ and both template and probe DNA denatured simultaneously at $95^{\circ} \mathrm{C}$ for 6 min before quencing on ice and hybridising overnight at $42^{\circ} \mathrm{C}$. The sections were mounted with DPX (dibutylphtalate-polystyrene-xylene) and examined by light microscopy

Apoptosis detection. Detection of apoptotic cells by TUNEL (TdT-mediated dUTP nick-end labelling) assay was conducted using a Promega kit no. G. 325 'Apoptosis Detection System, Fluorescein', as directed in the kit manual. The samples were examined by fluorescence microscopy at $520 \pm 20 \mathrm{~nm}$.

Statistical analysis. From each prawn, 300 randomly selected cells were counted for statistical analysis of PO, peroxidase activity sites in the cells, and also for apoptotic cells. Paired sample $t$-test was used for comparing the mean percentage of spheroid cells that were $\mathrm{PO}$ positive and peroxidase positive, whilst independent-sample $t$-test was used for testing the mean percentage of apoptotic spheroid cells of laboratoryheld prawns compared to prawns with MCMS. SPSS ${ }^{\text {TM }}$ 8.0 program was used for conducting the $t$-test and alpha was 0.05 . Statistical correlations were also determined using the SPSS program.

\section{RESULTS}

\section{PO and peroxidase}

The results of $\mathrm{PO}$ and peroxidase tests on the LO of Penaeus monodon (Figs. 1 \& 2 respectively) showed $\mathrm{PO}$ and peroxidase activity was localized in spheroid cells and seen as dark brown to black granule staining. By contrast, the stromal matrix cells remained unstained or showed pale brown staining. From 300 counts of LO cells, the mean percentage of spheroid cells positive for $\mathrm{PO}$ and peroxidase was $83.5 \pm 23.3 \%$ and $81.6 \pm 22.9 \%$, respectively. There was no significant difference in the number of sites for $\mathrm{PO}$ and peroxidase activity in the spheroid cells $(t=0.117$, $\mathrm{df}=29$, $p>0.05)$. There was no correlation between the percentage of $\mathrm{PO}$ and peroxidase positive spheroid cells and weight of the prawn $(\mathrm{r}=-0.075$ for $\mathrm{PO}$ and $\mathrm{r}=$ -0.006 for peroxidase)

\section{In situ hybridization}

In situ tests with the rRNA probe showed that spheroid cells were explicitly differentiated by strong, blue hybridization signals from the pink staining stromal matrix cells (Fig 3). This indicated that spheroid cells had high 18S rRNA translating activity, suggestive of a higher metabolic rate than the stromal matrix cells The lumens of LO tubules often contained haemocytes and tubule endothelial cells sometimes stained blue.

\section{Apoptosis}

Both batches of prawns, those kept in the laboratory and those diagnosed with MCMS, sometimes showed apoptotic spheroid cells. The green colour of apoptotic spheroid cells due to fluorescein-12-dUTP staining was stronger in prawns with MCMS (Figs. 4 \& 5) and the mean percentage of apoptotic cells for them was significantly higher $(t=-5.533, \mathrm{df}=58, \mathrm{p}<0.05)$ at $79.9 \pm 12.3 \%$ than for laboratory-held prawns (Fig. 6) at $52.5 \pm 24.2 \%$.

\section{Area analysis}

Quantitative analysis of spheroid cells showed that there was no significant ( $p>0.05$ ) correlation between area and prawn length or weight. Similarly, there was no significant $(p>0.05)$ correlation between the ratio of spheroid cell area to total LO area and prawn length or weight. This lack of correlation was demonstrated for both laboratory-held and farmed prawns. However, 


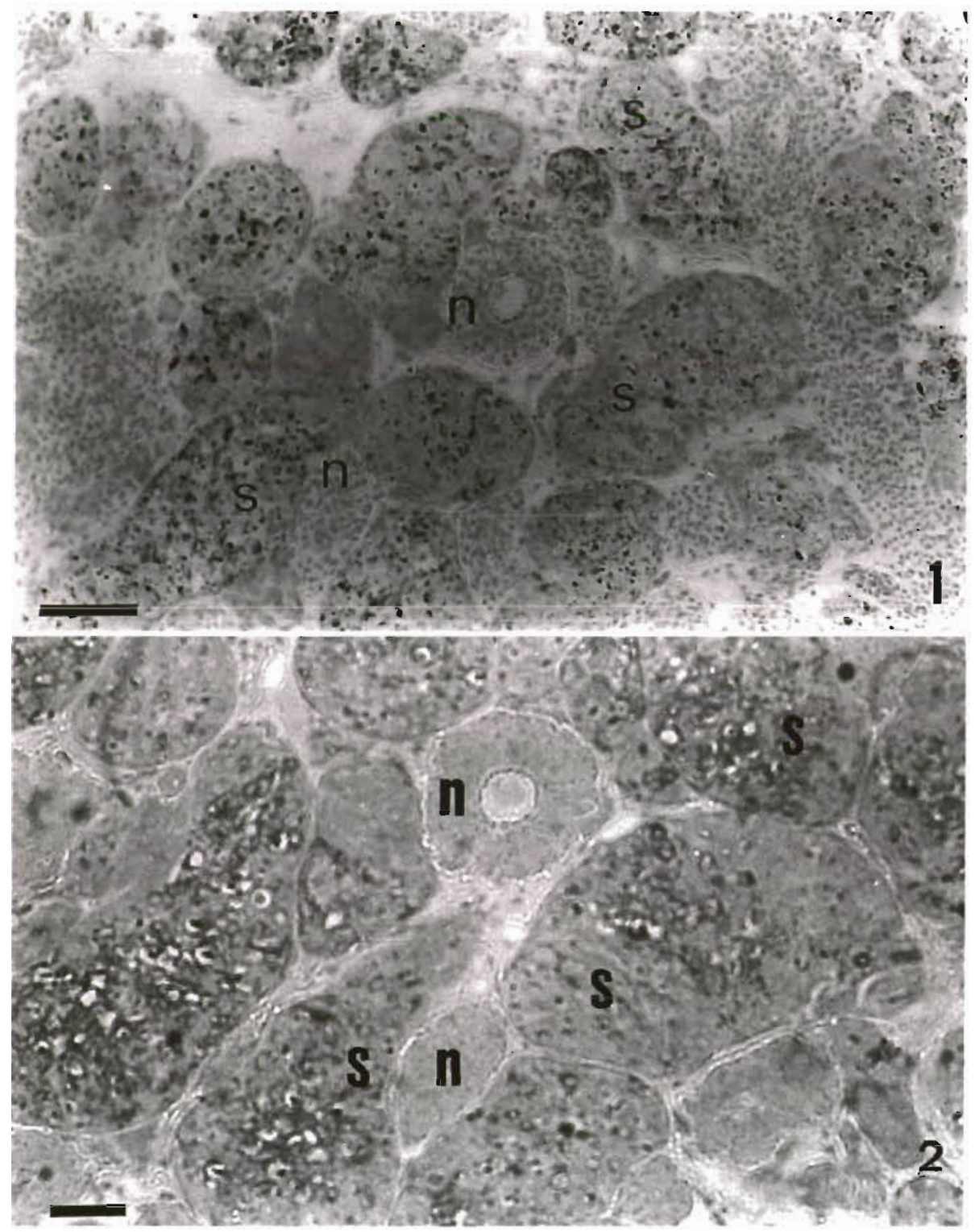

Figs. 1 \& 2. Light photomicrographs of lymphoid organ of Penaeus monodon stained with $\operatorname{DAB}$ (3,3-diaminobenzidine tetrahydrochloride) and with L-DOPA (dihydroxyphenilalanine) from one prawn on the same lymphoid organ site. Fig. 1. Spheroids (s), seen here as gray with darker gray and black spots, gave an overall brown colour and contained dark brown to black spots, indicative of a positive peroxidase reaction with $D A B$. Normal tubules $(\mathrm{n})$, seen here as lighter gray, remained unstained or stained very-lightly yellowbrown. Scale bar $=100 \mu \mathrm{m}$. Fig. 2. Spheroids (s), seen here as dark gray with darker gray and black spots, gave an overall dark brown colour and contained darker brown to black spots, both indicative of a positive phenoloxidase (PO) reaction with $\mathrm{L}$ DOPA. Normal tubules ( $n$ ), seen here as light grey, were unstained or very pale yellow-

brown. Scale bar $=60 \mu \mathrm{m}$

the laboratory-held prawns had a significantly higher area of spheroid cells $(t=3.52, \mathrm{df}=38, \mathrm{p}<0.05)$ and proportion of spheroid cells $(t=4.25, \mathrm{df}=36, p<0.05)$ than did the farmed prawns.

\section{DISCUSSION}

Researchers characterizing crustacean haemocytes have used several different criteria and terminologies. Morphologically, they can be categorised by the presence or absence of granules and this was used in early studies of penaeid haemocytes, as in Metapenaeus mastersii (Dall 1964), Sicyonia ingentis, Penaeus californiensis (Martin \& Graves 1985), and Penaeus japonicus (Tsing et al. 1989). Martin \& Graves (1985) classified them as agranular, semi-granular or large granular haemocytes. Similarly, Tsing et al. (1989) classified them as undifferentiated haemocytes (UH), small granular haemocytes (SGH) or large granular haemocytes (LGH). Neither the term 'agranular' nor the term 'undifferentiated' is correct. We will use Tsing's classification here but use the word hyalinocyte ( $\mathrm{HC}$ ) for those celis that have no obvious granules under light microscopy, as this classification is the least presumptive.

Cytochemical studies on Sicyonia ingentis haemocytes by Hose et al. (1987) revealed that prophenoloxidase was localised in SGH and in LGH. In Penaeus japonicus, Sequeira et al. (1995) found that PO activity in both $\mathrm{SGH}$ and $\mathrm{LGH}$ but that peroxidase activity was confined to LGH. In addition, Sung et al. (1998) re- 
Fig. 3. Photomicrograph of a section of lymphoid organ of Penaeus monodon hybridized with a gene probe for the prawn 18S rRNA gene. Spheroid cells (s), seen here as dark gray to black, stained dark blue, indicating large quantities of rRNA. The staining contrasted sharply with the stromal matrix cells of the normal tubules $(\mathrm{n})$, seen here as a lighter gray, but staining lightly pink with the counter stain, indicating a low quantity of rRNA. Stained with DIG and counter stained with neutral red. Scale bar $=20 \mu \mathrm{m}$

Figs. 4 \& 5. Photomicrograph of the lymphoid organ of Penaeus monodon diagnosed with midcrop mortality syndrome (MCMS) (see 'Material and methods'). Seen here as bright white against a dark background, nuclei stained with fluorescein12-dUTP gave a strong green fluorescence and were present in high numbers in spheroids ( $\star$ ). indicating a high number of cells undergoing DNA fragmentation, characteristic of apoptosis. By contrast, nuclei from normal tubules, seen here as darker gray, stained red/orange with propidium iodide, indicating no fragmented DNA. Scale bars: Fig. $4=$ $100 \mu \mathrm{m}$, Fig. $5=40 \mu \mathrm{m}$
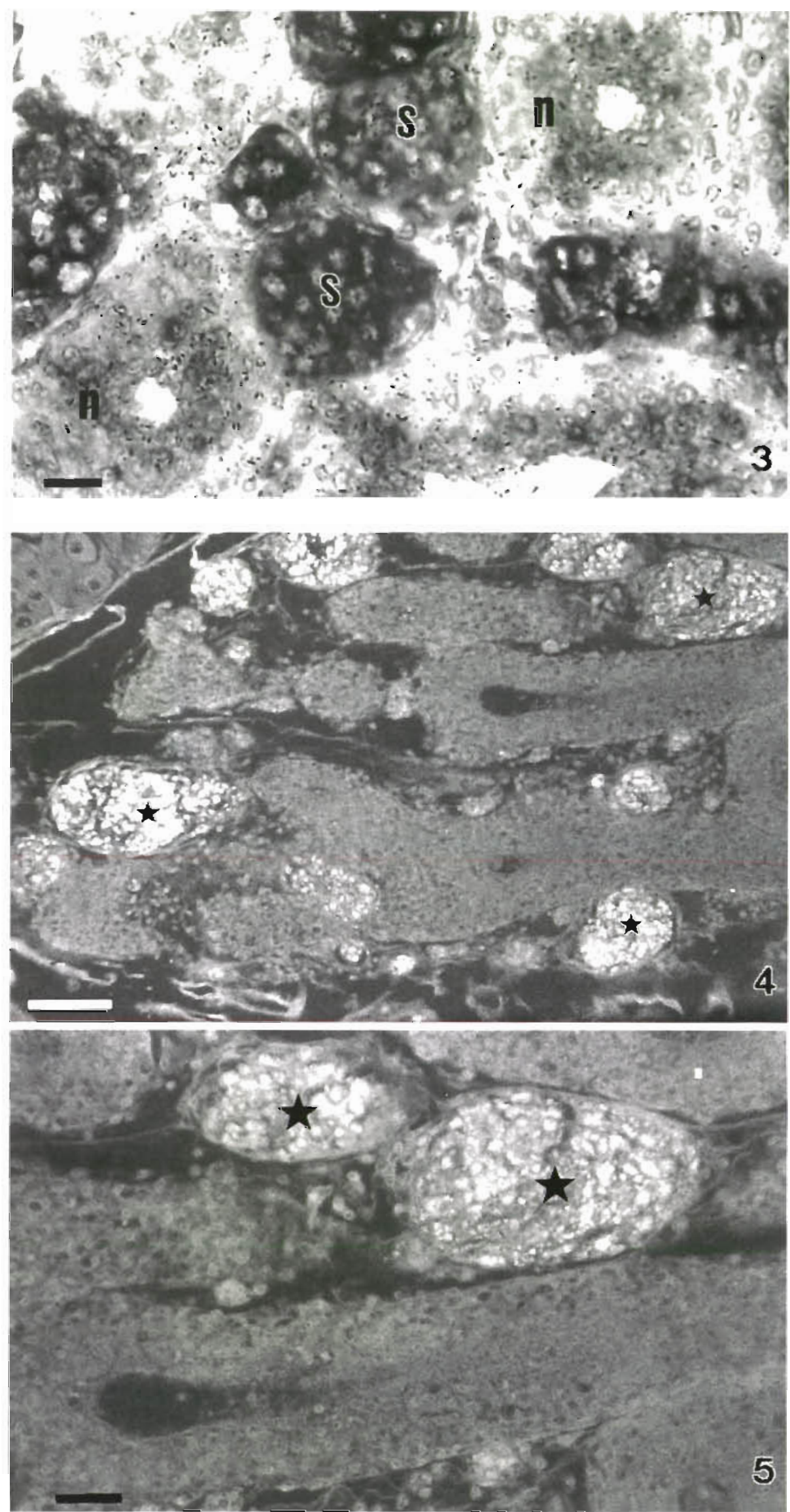


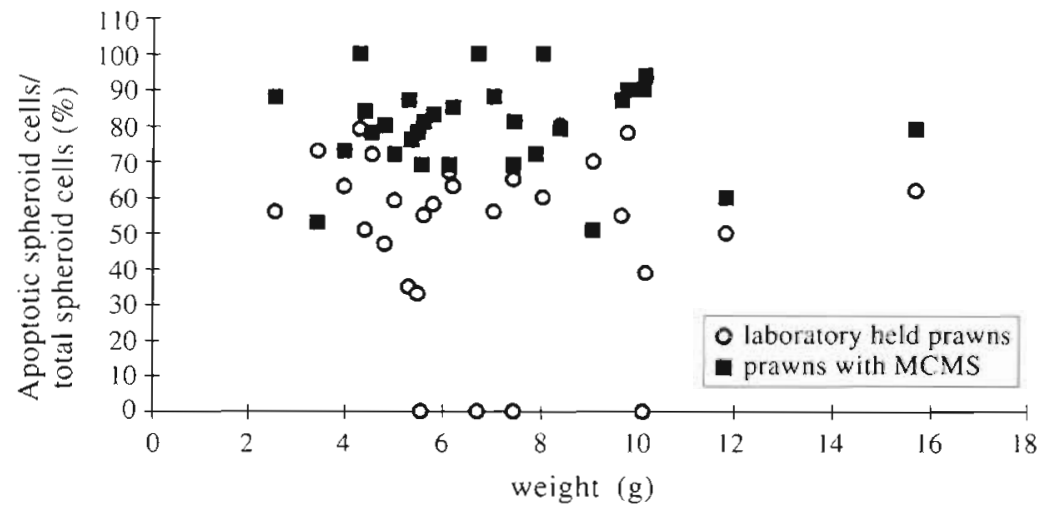

Fig. 6. Relationship between ratio of apoptotic spheroid cells to total spheroid cells in normal, laboratory-held Penaeus monodon and farmed P. monodon with MCMS. Prawns with MCMS had significantly higher ratios than normal prawns $(p<0.05)$. However, there was no correlation between these ratios and prawn weight $(\mathrm{p}>0.05)$ for either group

ported that the prophenoloxidase system existed in the granulocytes of tiger shrimp Penaeus monodon and the giant freshwater prawn Macrobrachium rosenbergii. However, the staining protocol they used could not determine whether the prophenoloxidase system was present in SGH. On the other hand in crayfish, Thornqvist \& Soderhall (1997) have shown that prophenoloxidase and inactive peroxinectin are present in both SGH and LGH granules and that they are specifically activated upon exocytosis. Peroxinectin exhibits both opsinin and peroxidase activities (Johansson et al. 1995). Obviously, the ability to measure these activities depends upon whether the zymogens have been activated or not. In summary, these papers suggest that in penaeids $\mathrm{HC}$ have no granules and no $\mathrm{PO}$ or peroxidase activity. Small granular haemocytes have granules and prophenoloxidase but no peroxidase. Large granule haemocytes have granules, prophenoloxidase and peroxidase. However in crayfish, both SGH and LGH have both $\mathrm{PO}$ and peroxidase

Cytochemically, the present study showed that speroid cells of Penaeus monodon had similar characteristics to SGH and LGH due to their staining for PO and peroxidase activity. Morphologically, by light microscopy, spheroid cells were not granulated. Thus, if they originated from granular haemocytes, then exocytosis of granules would have had to occur in another site or during spheroid formation and they would then consist of spent haemocytes. Given our results and the background information, we feel that the most parsimonious interpretation is that LOS cells are exocytosed (i.e., spent) granular haemocytes.

Research by Martin \& Hose (1992) on LO of Sicyonia ingentis showed that haemocytes must pass the thin intimal layer of endothelial cells to enter the circulation and that all of the 3 types of haemocytes are present in the tubule wall and embedded in stromal matrix cells.
Following this, Martin et al. (1996) showed that injection of radiolabelled bacteria into the haemolymph of $S$, ingentis resulted in its localisation in gills, heart, abdominal musculature and what they called haematopoietic nodules but what are obviously LO by our interpretation of the published figures of Martin \& Hose (1992). They found the latter the most specific and effective organ for bacterial clearance. There is no evidence of high mitotic activity in either the matrix or the spheroid cells, suggesting that the LO is not a haematopoietic tissue.

Thus, our conclusions differ from those of Martin \& Hose (1992). The fact that stromal matrix cells showed limited staining for peroxidase and $\mathrm{PO}$ activity, whilst spheroid cells were extremely positive, could be interpreted in several ways, but we favour the following hypothesis: We propose that LOS cells have a haemocytic origin and that matrix cells do not. We suggest that spheroid cells begin as haemocytes that migrate from the LO tubule lumen, through the stromal matrix as phagocytic cells, contributing to the phagocytic nature of the stromal matrix. We further hypothesise that this is part of the normal haemocyte migratory route from the dorsal aorta and heart, through the stromal matrix area into the haemal sinuses behind the stromal matrix and thence to the main haemocoel. This is consistent with the haemolymph flow but opposite to the direction of cell movement proposed by Martin \& Hose (1992). Our supposition is supported by the work of Kondo et al. (1994), who showed that injected substances localised immediately in the lymphoid arteriolar tubules and only months later in sinusoidal spheroids.

Spheroid cells have not been associated with bacterial infections in any published work that we are aware of. Conversely, spheroid cells have been found associated with many, if not all, systemic viral infections, i.e., 'Nakamura organ' hypertrophy and metastasis (Lightner et al. 1987), lymphoidal parvo-like virus (Owens et al. 1991, 1992), LO vacuolization virus (Bonami et al. 1992), rhabdovirus of penaeid shrimp (Nadala et al. 1992), yellow head virus (Boonyaratpalin et al. 1993), LO virus (Spann et al. 1995, 1997), spawner-isolated mortality virus (Fraser \& Owens 1996) and Taura virus (Hasson et al. 1995). Therefore, we suggest that spheroid cells represent a major mechanism for sequestering viruses in penaeid prawns.

Apoptosis plays an important role in the defence system by removing unwanted and potentially dangerous cells such as self-reactive lymphocytes, virus-infected cells and tumour cells (Wyllie et al. 1980, Raff 1992, 
Martin et al. 1994, Steller 1995). According to our TUNEL assays, the numbers of apoptotic spheroid cells were higher and the TUNEL assay signal was stronger in LO of prawns with MCMS. However, this requires further study, since the apoptosis detection kit labels the $3^{\prime}-\mathrm{OH}$ end of DNA in general, and this may include viral DNA in addition to fragmented DNA of apoptotic cells. Thus, there was a slight possibility that viral DNA inside the spheroid cells was TUNEL labeled, resulting in an erroneously high percentage of apparently apoptotic cells in prawns with MCMS. Indeed many viruses have been found to replicate in the spheroids of prawns (see above). A major implication of this work is that prawns must be capable of viral recognition for phagocytosis and sequestering to occur.

It is well known that the stages of the moulting cycle in Crustacea influence their physiology, behaviour, reproduction, and immunity. The moulting cycle of penaeid prawns can be divided into 4 main stages (Schafer 1968, Read 1977, Huner \& Colvin 1979, Longmuir 1983, Robertson et al. 1987). These stages are: early postmoult (Stage A), late postmoult (Stage B), intermoult (Stage C), and premoult (Stage $D_{0}, D_{1}, D_{2}, D_{3}$ including ecdysis as Stage E). There was a correlation between immunological state and moult stage in penaeid prawns including Penaeus japonicus (Tsing et al. 1987. Sequeira et al. 1995) and Penaeus stylirostris (LeMoullac et al. 1997). Sequeira et al. (1995) found that the percentage of SGH and LGH increased during intermoult (Stage $\mathrm{C}$ ) in both female and male prawns and during premoult (Stage $\mathrm{D}_{0}$ ) in female prawns. The percentage of hyaline haemocytes declined in both female and male prawns at these times. PO activity measured in haemocytes was also significantly higher in intermoult than in premoult (LeMoullac et al. 1997). Further study on moult cycle of Penaeus indicus by Vijayan et al. (1997) showed that moult cycle duration was greater with increasing animal size. If spheroid cells accumulated in haemal sinuses of LO over the life of a prawn, the area of spheroid cells would be expected to increase with increasing prawn size. However, the area of spheroid cells was not correlated to any measure of size of the prawn. It is hypothesised that the spheroid cells are disposed of, possibly with moulting, and this hypothesis is now being investigated.

In conclusion, we propose that lymphoid spheroid cells have the characteristics of exocytosed, granular haemocytes that have phagocytosed foreign material, particularly viruses, and that they are probably the major mechanism for penaeid antiviral defense.

Acknowledgements. This research was funded by the Australian Center for International Agricultural Research (ACIAR), Project Number 9411: Prawn Health Management and Disease Control to Sustain Hatchery and Pond Production System.

\section{LITERATURE CITED}

Adams A (1994) Teaching papers on Basic Immunology Workshop, Bangkok, Thailand, October 24-28, 1994. Overseas Development Agency (ODA) SEAADCP/AAHRI. Aquatic Animal Health Research Institute, Bangkok

Aspan A, Soderhall K (1991) Purification of prophenoloxidase from crayfish blood cells, and its activation by an endogenous serine proteinase. Insect Biochem 21:363-373

Bauchau AG (1981) Crustaceans. In: Ratcliffe NA, Rowley AF (eds) Invertebrate blood cells, Vol 2. Academic Press, New York, p 386-420

Bell TA, Lightner DV (1988) A handbook of normal penaeid shrimp histology. World Aquaculture Society. Allen Press, Lawrence, KS

Bonami JR, Lightner DV, Redman RM, Poulos BT (1992) Partial characterization of togavirus (LOVV) associated with histopathological changes of the lymphoid organ of penaeid shrimps. Dis Aquat Org 14:145-152

Boonyaratpalin S, Supamattaya K, Kasornchandra J, Direkbusaracom S, Aekpanithanpong U, Chantanachooklin C (1993) Non-occluded baculo-like virus, the causative agent of yellow head disease in the black tiger shrimp (Penaeus monodon). Fish Pathol (Gyobyo Kenkyu) 28(3): $103-109$

Dall W (1964) Studies on the physiology of a shrimp, Metapenaeus mastersii (Haswell) (Crustacea: Decapoda: Penaeidae). Aust J Mar Freshw Res 15:145-161

Deimann W (1984) Endogenous peroxidase activity in mononuclear phagocytes. Progr Histochem Cytochem 15(2):1-9

Fahimi HD (1979) An assessment of the DAB methods for cytochemical detection of catalase and peroxidase. J Histochem Cytochem 27:1365-1366

Fontaine CT, Lightner DV (1974) Observations on the phagocytosis and elimination of carmine particles injected into the abdominal musculature of the white shrimp, Penaeus setiferis. J Invertebr Pathol 24:141-148

Fraser CA, Owens L (1996) Spawner-isolated mortality virus from Australian Penaeus monodon. Dis Aquat Org 27 : $141-148$

Hasson K, Lightner DV, Poulos BT, Redman RM, White BL, Brock JA, Bonami JR (1995) Taura syndrome in Penaeus vannamei: demonstration of a viral aetiology. Dis Aquat Org 23:115-126

Hose JE, Martin GG, Nguyen VA, Lucus J, Rosenstein T (1987) Cytochemical features of shrimp hemocytes. Biol Bull 173:178-187

Huner JV, Colvin LB (1979) Observations on the molt cycles of two species of juvenile shrimp, Penaeus californiensis and Penaeus stylirostris (Decapoda:Crustacea). Proc Natl Shellfish A.ssoc 69:77-84

Johansson MW, Soderhall K (1985) Exocytosis of the prophenoloxidase activating system from crayfish haemocytes. J Comp Physiol 156B:175-181

Johansson NW, Soderhall K (1989) Cellular immunity in crustaceans and the prophenoloxidase system. Parasitol Today 5:171-176

Johansson MW, Lind MI, Holmblad T, Thornquist PO, Soderhall K (1995) Peroxinectin, a novel cell adhesion protein from crayfish blood. Biochem Biophys Res Commun 216: $1079-1087$

Kim W, Abele LG (1990) Molecular phylogeny of selected decapod crustaceans based on 18S IRNA nucleotide sequences. J Crustac Biol 10:1-13

Kondo M, Matsuyama $H$, Yano $T$ (1992) The opsonic effect of lectin on phagocytosis by hemocytes of kuruma prawn, Penaeus japonicus. Fish Pathol 27:217-222 
Kondo M, Itami T, Takahashi Y, Fujii R, Tomonaga S (1994) Structure and function of the lymphoid organ in the kuruma prawn. Dev Comp Immunol 18(Suppl 1):S109

LeMoullac $G$, Le-Groumellec $M$. Ansquer D. Froissard $S$, Levy P. Aquacop (1997) Haematological and phenoloxidase activity changes in the shrimp Penaeus stylirostris in relation with the moult cycle: protection against vibriosis. Fish Shellfish Immunol 7:227-234

Lightner DV (ed) (1996) A handbook of shrimp pathology and diagnostic procedures for diseases of cultured penaeid shrimp. World Aquaculture Society, Baton Rouge

Lightner DV, Hedrick RP, Fryer JL, Chen SN, Liao IC, Kou GH (1987) A survey of cultured penaeid shrimp in Taiwan for viral and other important disease. Fish Pathol 22(3): $127-140$

Lillie RD, Fullmer HM (1976) Histopathologic technic and practical histochemistry, 4th edn. McGraw-Hill Inc, New York

Longmuir E (1983) Setal development, moult-staging and ecdysis in the banana prawn Pendeus merguensis. Mar Biol 77:183-190

Martin GG, Graves BL (1985) Fine structure and classification of shrimp hemocytes. J Morphol 185:3.39-348

Martin GG, Hose JE (1992) Vascular elements and blood (hemolymph). In: Harrison FW, Humes AG (eds) Microscopic anatomy of invertebrates, Vol 10, Chap 5: Decapod Crustacea. Wiley-Liss, New York, p 117-146

Martin GG, Hose JE, Kim JJ (1987) Structure of haematopoietic nodules in the ridgeback prawn, Sicyonia ingentis light and electron microscopic observations. J Morphol 192:193-204

Martin GG, Hose JJ, Minka G, Rosenberg S (1996) Clearance of bacteria injected into the haemolymph of the ridgeback prawn, Sicyonia ingentis (Crustacea: Decapoda): role of hematopoietic tissue. J Morphol 227:227-233

Martin SJ, Green DR, Cotter TG (1994) Dicing with death: dissecting the components of the apoptosis machinery. TIBS 19:26-30

Nadala ECB Jr, Lu Y, Loh PC, Brock JA (1992) Infection of Penaeus stylirostris (Boone) with a rhabdovirus isolated from Penaeus spp. Fish Pathol (Gyobyo Kenkyu) 27: $143-147$

Oka M (1969) Studies on Penaeus orientalis Kishinuoye-VIII structure of the newly found lymphoid organ. Bull Jpn Soc Sci Fish 35:245-250

Owens L, Hall-Mendelin S (1.990) Recent advances in Australian penaeid diseases and pathology. Advances in Tropical Aquaculture, Tahiti (1989). Actes Collog 9:102-112

Owens L, De Beer S, Smith J (1991) Lymphoidal parvoviruslike particles in Australian penaeid prawns. Dis Aquat Org 11:129-134

Owens L, Anderson IG, Kenway M, Trott L, Benzie JAH (1992) Infectious hypodermal and haematopoietic necrosis virus (IHHNV) in a hybrid penaeid prawn from tropical Australia. Dis Aquat Org 14:219-228

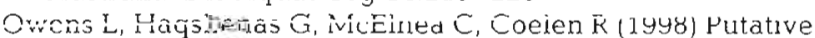
spawner-isolated mortality virus associated with mid-crop mortality syndrome in farmed Penaeus monodon from northern Australia. Dis Aquatic Org 34:177-185

Raff MC (1992) Soclal control on cell survival and cell death.
Nature 356:397-400

Read GLH (1977) Aspects of lipid metabolism in Penaeus indicus Milne Edwards. Masters thesis, University of Natal

Robertson L. Bray W, Leung-Trujillo J, Lawrence A (1987) Practical molt staging of Penaeus setiferus and Penaeus stylirosis. I World Aquacult Soc 18:180-185

Schafer HJ (1968) The determination of some stages of the moulting cycle of Penzeus duorarum, by microscopic examination of the setae of the endopodites of pleopods. FAO Fish Rep 57:381-391

Sequeira T, Vilanova M, Lobo-da-Cunha A, Baldaia L, AralaChaves M (1995) Flow cytometric analysis of molt-related changes in hemocytes type in male and female Peneaus japonicus. Biol Bull 189:376-380

Smith VJ, Soderhall K (1983) $\beta$-1,3-glucan activation of crus tacean hemocytes in vitro and in vivo. Biol Bull 164 $299-314$

Smith VJ, Soderhall K, Hamilton M (1984) $\beta$-1,3-glucans induced cellular defence reactions in the shore crab Carcinus maenas. Comp Biochem Physiol 77 A:635-639

Soderhall K, Cerenius L (1992) Crustacean immunity. Annu Rev Fish Dis 2:3-23

Soderhall K, Smith VJ, Johansson MiW (1986) Exocytosis and uptake of bacteria by isolated haemocyte populations of two crustaceas: evidence for cellular co-operation in the defence reactions of arthropods. Cell Tissue Res 245 $43-49$

Song YL, Hsieh YT (1994) Immunostimulation of tiger shrimp (Penaeus monodon) hemocytes for generation of microbicidal substances: analysis of reactive oxygen species. Dev Comp Immunol 18:201-209

Spann KM, Vickers JE, Lester RJG (1995) Lymphoid organ virus of Penaeus monodon from Australia. Dis Aquat Org 23:127-134

Spann KM, Cowley JA, Walker PJ, Lester RJG (1997) A yellow-head-like virus from Penaeus monodon cultured in Australia. Dis Aquat Org 31:169-179

Steller H (1995) Mechanisms and genes of cellular suicide. Science 267:1445-1449

Sung $\mathrm{HH}$, Chang $\mathrm{HJ}$, Her $\mathrm{CH}$, Chang JC, Song YL (1998) Phenoloxidase activity of hemocytes derived from Penaeus monodon and Macrobrachium rosenbergii. J Invertebr Pathol 71:26-33

Thornquist PO, Soderhall K (1997) Crustacean immune reactions, a short review. In: Flegel TW, MacRae IH (eds) Diseases in Asian aquaculture III. Fish Health Section, Asian Fisheries Society, Manila, p 203-218

Tsing A, Arcier JM, Brehelin M (1989) Haemocytes of penaeid and palaemonid shrimps: morphology, cytochemistry and hemograms. J Invertebr Pathol 53:64-77

Vickers JE, Paynter JL, Spradbrow PB, Lester RJG (1993) An impression smear method for rapid detection of Penaeus monodon-type baculovirus (MBV) in Australian prawns. J Fish Dis 16:507-511

Vijayan KK, Mohamed KS, Diwan AD (1997) Studies on mnılt staging, moulting duration and moulting behaviour in Indian white shrimp Penaeus indicus Mine Edwards (Decapoda:Penaeidae). J Aquacult Trop 12:53-64

Wyllie AH, Kerr JF, Currie AR (1980) Cell death: the significance of apoptosis. Int Rev Cytol 68:251-306

Submitted: October 1, 1998; Accepted: December 13, 1999

Proofs received from author(s): February 22, 2000
Editorial responsibility: Timothy Flegel,

Bangkok, Thailand 